\title{
Communities of P-Solubilizing Bacteria, Fungi and Arbuscular Mycorrhizal Fungi in grass pasture and secondary forest of Paraty, RJ - Brazil*
}

\author{
EDSON L. SOUCHIE ${ }^{1}$, ORIVALDO J. SAGGIN-JÚNIOR ${ }^{2}$, ELIANE M.R. SILVA ${ }^{2}$, \\ EDUARDO F.C. CAMPELLO ${ }^{2}$, ROSARIO AZCÓN ${ }^{3}$ and JOSE M. BAREA ${ }^{3}$ \\ ${ }^{1}$ Centro Federal de Educação Tecnológica, Cx. Postal 66, 75901-970 Rio Verde, GO, Brasil \\ ${ }^{2}$ Embrapa Agrobiologia, Cx. Postal 101, 23890-970 Seropédica, RJ, Brasil \\ ${ }^{3}$ Estación Experimental del Zaidín, Dep. de Microbiología y Sistemas Simbióticos \\ Calle Prof. Albareda, no 0118008 Granada, España
}

Manuscript received on January 6, 2005; accepted for publication on September 12, 2005; presented by EURÍPEDES MALAVOLTA

\begin{abstract}
Communities of P-solubilizing bacteria, fungi and arbuscular mycorrhizal fungi, were evaluated in two different ecosystems. Samplings taken from two areas of Atlantic forest, in Paraty - RJ, Brazil, one with a secondary forest and the other with a grass pasture were studied. Four growth media: GL (glucose and yeast extract), GES (glucose, soil extract, $\mathrm{KNO}_{3}, \mathrm{CaCl}_{2}, \mathrm{MgSO}_{4}, \mathrm{NaCl}$, FeEDTA and micronutrients solution), GAGES (glucose, soil extract, arabinose, glycerol, $\mathrm{CaCl}_{2}, \mathrm{MgSO}_{4}$ and $\mathrm{NaCl}$ ) and GELP (glucose, soil extract, yeast extract, peptone, $\mathrm{CaCl}_{2}, \mathrm{MgSO}_{4}$ and $\mathrm{NaCl}$ ) were evaluated for the isolation of $\mathrm{P}$-solubilizing microorganisms. The identification of P-solubilizing bacteria was based on $16 \mathrm{~S}$ rDNA sequence analysis, while the identification of P-solubilizing fungi and arbuscular mycorrhizal fungi was based on morphology. The greatest number of P-solubilizing bacteria was isolated using GL and GELP growth media. The greatest number of P-solubilizing fungi was isolated using GAGES and GES. The bacteria were identified as Enterobacteriaceae and Bacillus sp., while the P-solubilizing fungi were identified as Aspergillus sp. Glomus macrocarpum and Glomus etunicatum were the dominant mycorrhizal fungi in the secondary forest and grass pasture area, respectively.
\end{abstract}

Key words: phosphate, Enterobacteriaceae, Atlantic Forest, Glomeromycota, soil microorganisms.

\section{INTRODUCTION}

Soil microbiota develops important functions in ecosystems, since it influences growth, mineral nutrition and plant health. Phosphorus is normally the most limiting nutrient in tropical soils and of the most important groups of the soil microbial community are the P-solubilizing microorganisms and

*Part of the thesis of the first author. Correspondence to: Edson Luiz Souchie

E-mail: esouchie@yahoo.com.br the arbuscular mycorrhizal fungi (AMF).

According to Silva Filho and Vidor (2000), the application of P-solubilizing microorganisms as inocula or the management of their populations in soil are alternatives to improve $\mathrm{P}$ availability for plants. These microorganisms have the ability to solubilize and mineralize $P$ from inorganic and organic pools of total soil $\mathrm{P}$, making the element available for plants. Gyaneshwar et al. (2002) suggested that $\mathrm{P}$-solubilizing microorganisms are ubiquitous in 
soils and could play an important role in supplying $\mathrm{P}$ to plants in a more environmentally and sustainable manner. According to Silva Filho (unpublished data), the community of P-solubilizing microorganisms in soils is around $10^{4}$ and $10^{7} \mathrm{CFU}$ (ColonyForming Units) $\mathrm{g}^{-1}$ of soil, depending of the area and the method of evaluation used.

AMF improve the absorption of $\mathrm{P}$ and other nutrients by plants increasing the contact surface and the explored soil volume (Clark and Zeto 2000) and possibly facilitating nutrient transport among plants (Chen et al. 2005). Moreover, plants colonized by AMF have alternative mechanisms to meet their nutritional demands and to maintain their physiological functions under abiotic stress conditions, such as drought stress (Ruiz-Lozano et al. 2001) and salinity (Azcón and El-Atrash 1997). According to Van Der Heijden et al. (2003) the composition of AMF communities determines how plant species coexist and to which plant species nutrients are allocated, affecting the plant succession, as suggested by Janos (1980). The AMF inoculation influence the competitive relations between tree pioneer species, decreasing or increasing the competition, according to P availability in soils (Flores-Aylas et al. 2003). The reduction of AMF infection under field conditions can decrease plant diversity affecting the secondary succession process (Gange et al. 1990). Therefore, the AMF communities in areas with rapid succession, as grass pasture and secondary forest, need to be more known. Generally, grass pasture presents greater potential of AMF inocula than secondary forests (Fischer et al. 1994). However, the AMF diversity and the relation between AMF and other soil microorganisms are still little explored.

There are several indications that bacteria have important functions in the interaction between roots and AMF (Fester et al. 1999). The interaction of P-solubilizing bacteria and AMF can also promote better establishment of AMF (Toro et al. 1997). According to Johansson et al. (2004) a better understanding of the interactions between AMF and other microorganisms is necessary for the development of sustainable management of soil fertility, crop production and probably, plant succession on reclamation areas. Although potential clearly exists for developing solubilizers and AMF such inoculants, their widespread application remains limited mainly by a poor understanding of microbial ecology and population dynamics in soil. Therefore, it is interesting to quantify these organisms in soils for their possible use as combined inocula, in order to obtain the maximum benefit to the development of plants. The aim of this study was to isolate and identify P-solubilizing bacteria, fungi and AMF species in two reclamation areas of the Atlantic Forest, in Paraty, Brazil, one of a secondary forest and other of a grass pasture. The ability to isolate P-solubilizing microorganisms was also compared using different growth media.

\section{MATERIALS AND METHODS}

Soil microorganisms were isolated from two areas around a conservation unit of Atlantic Forest (National Park of Serra da Bocaina), one with a secondary forest (SF) in a former banana crop area and the other a grass pasture (GP) in Paraty, southern Rio de Janeiro State, Brazil. The climate in this region is AW type with mean precipitation of 175 and $198 \mathrm{~mm}$ and temperature of $23.3^{\circ} \mathrm{C}$ and $22.8^{\circ} \mathrm{C}$ in April and November, respectively. Both areas were degraded by low input agriculture (SF) or intense grazing by animals (GP). The SF is located at $\mathrm{S} 23^{\circ} 9^{\prime} 39.9^{\prime \prime}$ and $\mathrm{W} 23^{\circ} 44^{\prime} 18.4^{\prime \prime}$ at an altitude of $342 \mathrm{~m}$ above sea level, on a steep slope. It is an ecosystem dominated by a secondary forest, showing less plant diversity compared to the primary forest. The GP area is located at S $24^{\circ} 8^{\prime} 40^{\prime \prime}$ and W $24^{\circ} 36^{\prime} 21.3^{\prime \prime}$ with an altitude of $402 \mathrm{~m}$ above sea level, on a steep slope, showing a prevalence of Axonopus sp. and Brachiaria decumbens, and containing points of exposed soil, indicating initial land degradation. Chemical and textural characteristics of the soils from both areas are shown in Table I.

Soil samples were taken from both areas, in April and November of 2000, into delimited areas of 0.5 ha. The samples were taken using a matrock 
TABLE I

Chemical and textural characteristics of the soils ${ }^{1}$ from secondary forest and grass pasture areas in Paraty - RJ.

\begin{tabular}{|c|c|c|c|c|c|c|c|c|c|c|}
\hline Area & $\begin{array}{c}\mathrm{pH} \\
\text { in water }\end{array}$ & $\mathrm{P}^{(2)}$ & $\mathrm{K}^{(2)}$ & $\mathrm{Ca}^{(3)}$ & $\mathrm{Mg}^{(3)}$ & $\mathrm{Al}^{(3)}$ & $\mathrm{C}^{(4)}$ & Texture & type & $\begin{array}{l}\text { Soil } \\
\text { class }\end{array}$ \\
\hline & $(2: 1)$ & $\mathrm{mg}$ & $m^{-3}$ & $-c$ & $\mathrm{~mol}_{\mathrm{c}} \mathrm{dm}^{-}$ & - & $\mathrm{g} \mathrm{kg}^{-1}$ & & & \\
\hline $\begin{array}{l}\text { Secondary } \\
\text { forest }\end{array}$ & 5.0 & 9.5 & 198 & 3.8 & 1.6 & 0.1 & 1.96 & sandy clay & loam & Litosoil \\
\hline $\begin{array}{l}\text { Grass } \\
\text { pasture }\end{array}$ & 4.8 & 3.0 & 125 & 1.0 & 1.1 & 0.9 & 1.81 & sandy clay & loam & Litosoil \\
\hline
\end{tabular}

${ }^{1}$ Soil samples were taken from the 0-20 cm layer; ${ }^{2}$ Extractor: Mehlich I; ${ }^{3}$ Extractor: KCl 1M; ${ }^{4}$ Embrapa (1997).

from the 0-20 $\mathrm{cm}$ layer at 10 different points in each area to obtain a representative analysis. Generally, 20 samples per hectare are sufficient to soil characteristics analysis (Embrapa 1997). In each collect point, litter was taken out from the soil surface. Samples were gathered forming a mixed sample for each area and transported in plastic bags to Embrapa Agrobiologia. Larger roots were taken out manually from each mixed sample. These samples were then transferred to plastic pots and cultivated with Mimosa caesalpiniifolia, as a trap plant for P-solubilizing microorganisms. After 45 days of cultivation, under greenhouse conditions, eight plants, from each soil sample, were harvested and these microorganisms were isolated from $10 \mathrm{~g}$ of soil collected from the rhizoplane plus rhizosphere of the plants. The $10 \mathrm{~g}$ of soil were directly mixed in $90 \mathrm{ml}$ of $\mathrm{NaCl}(0,85 \%)$, following the successive dilutions method to $10^{-5}$. From each dilution, $100 \mu \mathrm{l}$ were transferred to sterilized Petri plates, followed immediately by the addition of media maintained to $45^{\circ} \mathrm{C}$ ("Pour-Plate" method). A control without soil to verify contaminations was used transferring $100 \mu \mathrm{l}$ of $\mathrm{NaCl}(0,85 \%)$ to Petri plates adding the growth media. Four growth media were evaluated for the isolation of P-solubilizing bacteria and fungi: GL ( $10 \mathrm{~g}$ of glucose, $2 \mathrm{~g}$ of yeast extract and $15 \mathrm{~g}$ of agar); GES (10 g of glucose, $100 \mathrm{ml}$ of soil extract, $0.1 \mathrm{~g}$ of $\mathrm{KNO}_{3}, 2 \mathrm{ml}$ of $\mathrm{CaCl}_{2} 1 \%, 2 \mathrm{ml}$ of $\mathrm{MgSO}_{4}$ $10 \%, 1 \mathrm{ml}$ of $\mathrm{NaCl} 10 \%, 4 \mathrm{ml}$ of FeEDTA $1.64 \%$, $2 \mathrm{ml}$ of micronutrients solution and $15 \mathrm{~g}$ of agar);
GAGES (10 $\mathrm{g}$ of glucose, $100 \mathrm{ml}$ of soil extract, $5 \mathrm{~g}$ of arabinose, $4 \mathrm{ml}$ of glycerol, $2 \mathrm{ml}$ of $\mathrm{CaCl}_{2} 1 \%$, $2 \mathrm{ml}$ of $\mathrm{MgSO}_{4} 10 \%, 1 \mathrm{ml}$ of $\mathrm{NaCl} 10 \%$ and $15 \mathrm{~g}$ of agar) and GELP (10 g of glucose, $100 \mathrm{ml}$ of soil extract, $0.05 \mathrm{~g}$ of yeast extract, $5 \mathrm{~g}$ of peptone, $2 \mathrm{ml}$ of $\mathrm{CaCl}_{2} 1 \%, 2 \mathrm{ml}$ of $\mathrm{MgSO}_{4} 10 \%, 1 \mathrm{ml}$ of $\mathrm{NaCl} 10 \%$ and $15 \mathrm{~g}$ of agar). $\mathrm{CaCl}_{2}(10 \%)$ and $\mathrm{K}_{2} \mathrm{HPO}_{4}(10 \%)$ were sterilized separately and added to the media, before adding to the Petri plates, to produce an inorganic phosphate precipitate $\left(\mathrm{CaHPO}_{4}\right)$.

The experiment was set up in a completely randomized design $4 \times 2$ (four growth media $\times$ two sample areas, SF and GP), with three replicates for each dilution. Variance analysis was performed using the statistical package SISVAR (Ferreira 1999). The density of P-solubilizing bacteria and fungi as well as total bacteria and fungi was evaluated through direct counting in plates from dilutions $10^{-2}, 10^{-3}$, $10^{-4}$ and $10^{-5}$. Results were expressed as Colony Forming Units (CFU).

Dilutions from $10^{-3}$ to $10^{-5}$ were used for purification of P-solubilizing microorganisms (purified in Petri plates containing the same isolation medium) because they showed better colony separation. Purified microorganisms were stored at room temperature in test tubes containing GL medium and mineral oil for posterior use in taxonomic studies carried out at Estación Experimental del Zaidín (Granada), Spain. The difficulties to transport alive microorganims to Spain limited the number of isolated to be taxonomic studied, being just chosen 
those more promising regarding $\mathrm{P}$ solubilization. Thus, two P-solubilizing fungi isolates (7 and 9) and three P-solubilizing bacteria isolates $(8,9$ and 50) from Paraty were chosen based on the larger diameter of the solubilization halo as compared to the other isolates, indicating a higher ability for P solubilization. As controls for taxonomic studies, Psolubilizing microorganisms were isolated and purified (using GL medium) from rhizoplane plus rhizosphere of M. caesalpiniifolia cultivated in a soil sample from Pontevedra, Galicia (Spain), collected at $\mathrm{N} 42^{\circ} 24^{\prime} 19.1^{\prime \prime}$ and $\mathrm{W} 8^{\circ} 40^{\prime} 22.8^{\prime \prime}$, altitude of $80 \mathrm{~m}$, in a zone with typical vegetation of temperate forest. The composition of the Spanish soil was: total sand $=72 \%$; silt $=18 \%$; clay $=10 \% ; \mathrm{pH}=5.4 ; \%$ organic $\mathrm{C}=1.9$; total $\mathrm{N}=2330 \mathrm{mg} \mathrm{dm}^{-3}$ and available $\mathrm{P}$ $($ Olsen $)=21 \mathrm{mg} \mathrm{dm}^{-3}$. The methodology used for isolation was the same described above and, therefore, one more P-solubilizing fungi isolate (19) and one P-solubilizing bacteria isolate (55) from Galicia were chosen based on larger solubilization halo for taxonomic studies.

AMF spores were extracted directly from mixed soil samples from two areas, by wet sieving (Gerdemann and Nicolson 1963) and centrifugation in sucrose solution (Jenkins 1964) and then collected on a sieve of $53 \mu \mathrm{m}$. The spores were placed into Petri plates for counting and separation using a stereoscopic microscope. Slides containing representative amounts of each type of spore were prepared and used to identify the AMF species present in both areas of Paraty.

P-solubilizing fungi were identified based on their morphology through the evaluation of a small piece of GL medium containing the fungal structures, using a stereoscopic microscope. Genera were assigned to the P-solubilizing fungi isolates according to the results and information from Barnett and Hunter (1972).

DNA was obtained from the P-solubilizing bacteria after growth in GL medium as described by Giovannetti et al. (1990). Identification of the isolates was based on 16S rDNA sequences. PCR amplification using universal primers $27 \mathrm{f}$ and $1495 \mathrm{r}$
(Lane 1991) was carried out in $20 \mu \mathrm{L}$ containing $0.5 \mathrm{mM}$ of each primer, $100 \mathrm{mM}$ of DNTPs, PCR $1 \mathrm{X}$ buffer (Sigma, St. Louis, MO, USA), $2.5 \mathrm{mM}$ of $\mathrm{MgCl}_{2}, 10 \mathrm{ng}$ of genome DNA and $0.25 \mathrm{U}$ of Taq DNA polymerase (Sigma).

A Perking Elmer/Cetus thermocycler was used with the following parameters: initial denaturation at $95^{\circ} \mathrm{C}$ for $4 \mathrm{~min}$, followed by 30 cycles of denaturation at $94^{\circ} \mathrm{C}$ for 30 seconds, annealing at $56^{\circ} \mathrm{C}$ for 45 seconds, elongation at $72^{\circ} \mathrm{C}$ for $1 \mathrm{~min}$, and final elongation at $72^{\circ} \mathrm{C}$ for $5 \mathrm{~min}$. Amplified DNA was purified from agarose gel (1.2\%) using the QIAEX II Extraction Kit (Qiagen, Hilden, Germany) and cloned in pGME (Promega), for sequencing. The 16S sequences obtained from isolates were analyzed using BLAST and FASTA algorithms in order to identify the genus and where possible, the P-solubilizing bacteria species.

Phylogenetic analysis of the P-solubilizing bacteria isolates was performed using the multiple sequence alignment program CLUSTALW (version 1.5). The tree was generated using the PHYLIP software package.

\section{RESULTS}

In both samplings, taken in April and November, the growth media GL and GELP showed a more defined solubilization halo around the colonies. These were also the only media that isolated P-solubilizing bacteria in the SF samples in April (Table II). In the samples from the GP area, P-solubilizing bacteria were detected only by GAGES and GELP media. In November, P-solubilizing bacteria in samples from both areas were isolated using GL, GELP and GAGES media.

In April, P-solubilizing fungi were detected only in the soil from SF using GAGES medium (Table III). In November, P-solubilizing fungi in the soil samples from SF were detected using all growth media. These fungi were not detected in any samplings from the GP area.

The GL, GES and GAGES media did not show significant differences on isolation of total bacteria 
TABLE II

Populations of P-solubilizing and total bacteria obtained by different growth media from soil samples gathered in secondary forest (SF) and grass pasture (GP) in April and November, 2000, in Paraty, RJ.

\begin{tabular}{|c|c|c|c|c|c|c|c|c|c|}
\hline \multirow{3}{*}{ Growth media } & \multicolumn{3}{|c|}{ P-solubilizing bacteria } & \multicolumn{5}{c|}{ Total bacteria } \\
\cline { 2 - 9 } & \multicolumn{2}{|c|}{ April } & \multicolumn{2}{c|}{ November } & \multicolumn{2}{c|}{ April } & \multicolumn{2}{c|}{ November } \\
\cline { 2 - 9 } & SF & GP & SF & GP & SF & GP & SF & GP \\
\hline & \multicolumn{7}{|c}{ CFU $\times 10^{3} \mathrm{~g}^{-1}$ of dry soil } \\
\hline GL & $4,3 \mathrm{a}^{*}$ & $0 \mathrm{a}$ & $6,0 \mathrm{a}^{*}$ & $2,1 \mathrm{a}$ & $123 \mathrm{a}$ & $111 \mathrm{a}$ & $138 \mathrm{a}$ & $113 \mathrm{a}$ \\
\hline GES & $0 \mathrm{~b}$ & $0 \mathrm{a}$ & $0 \mathrm{~b}$ & $0 \mathrm{a}$ & $83 \mathrm{a}$ & $93 \mathrm{a}$ & $96 \mathrm{~b}$ & $77 \mathrm{ab}$ \\
\hline GAGES & $0 \mathrm{~b}$ & $0,4 \mathrm{a}$ & $0,8 \mathrm{~b}$ & $1,3 \mathrm{a}$ & $94 \mathrm{a}$ & $86 \mathrm{a}$ & $74 \mathrm{~b}$ & $62 \mathrm{~b}$ \\
\hline GELP & $3,0 \mathrm{a}^{*}$ & $0,6 \mathrm{a}$ & $1,6 \mathrm{~b}$ & $1,3 \mathrm{a}$ & $104 \mathrm{a}^{*}$ & $37 \mathrm{~b}$ & $42 \mathrm{c}^{*}$ & $18 \mathrm{c}$ \\
\hline
\end{tabular}

Means followed by same letter, on column, do not differ by Tukey test $(\mathrm{p} \leq 0.05)$; *superior mean between $\mathrm{SF}$ and GP areas by Tukey test $(\mathrm{p} \leq 0.05)$.

TABLE III

Populations of P-solubilizing and total fungi obtained by different growth media from soil samples gathered in secondary forest (SF) and grass pasture (GP) in April and November, 2000, in Paraty, RJ.

\begin{tabular}{|c|c|c|c|c|c|c|c|c|c|}
\hline \multirow{3}{*}{ Growth Media } & \multicolumn{3}{|c|}{ P-solubilizing fungi } & \multicolumn{5}{c|}{ Total fungi } \\
\cline { 2 - 9 } & \multicolumn{2}{|c|}{ April } & November & \multicolumn{2}{c|}{ April } & \multicolumn{2}{c|}{ November } \\
\cline { 2 - 9 } & SF & GP & SF & GP & SF & GP & SF & GP \\
\hline & 0 CFU $\times 10^{3} \mathrm{~g}^{-1}$ of dry soil \\
\hline GL & $0 \mathrm{a}$ & $0 \mathrm{a}$ & $5,6 \mathrm{~b}^{*}$ & $0 \mathrm{a}$ & $6,1 \mathrm{a}$ & $6,6 \mathrm{a}$ & $2,4 \mathrm{~b}$ & $3,1 \mathrm{a}$ \\
\hline GES & $0 \mathrm{a}$ & $0 \mathrm{a}$ & $15,4 \mathrm{a}^{*}$ & $0 \mathrm{a}$ & $3,9 \mathrm{a}$ & $4,4 \mathrm{a}$ & $2,0 \mathrm{~b}$ & $4,3 \mathrm{a}$ \\
\hline GAGES & $0,4 \mathrm{a}^{*}$ & $0 \mathrm{a}$ & $15,0 \mathrm{a}^{*}$ & $0 \mathrm{a}$ & $6,0 \mathrm{a}$ & $7,5 \mathrm{a}$ & $0,4 \mathrm{~b}$ & $3,9 \mathrm{a}^{*}$ \\
\hline GELP & $0 \mathrm{a}$ & $0 \mathrm{a}$ & $3,2 \mathrm{~b}$ & $0 \mathrm{a}$ & $8,6 \mathrm{a}^{*}$ & $6,5 \mathrm{a}$ & $14,6 \mathrm{a}^{*}$ & $3,0 \mathrm{a}$ \\
\hline
\end{tabular}

Means followed by same letter, on column, do not differ by Tukey test $(\mathrm{p} \leq 0.05)$; *superior mean between $\mathrm{SF}$ and GP areas by Tukey test $(\mathrm{p} \leq 0.05)$.

between the two areas during both sampling periods, but GELP medium isolated a higher number of bacteria colonies in the SF (Table II). However, comparing the media, GELP isolated lower bacteria colonies in the GP area in April and in both areas, in November. In this last sampling period, the differences among media were more evident, and the medium GL promoted the highest isolation of total bacteria.

The highest number of total fungi colonies was isolated using GELP medium in the SF area in November (Table III). In the other samplings the media did not differ to each other. A greater number of total fungi colonies were isolated from SF using GELP medium in April and November and from GP using GAGES medium in November.

The number of AMF spores in $50 \mathrm{ml}$ of soil from the first sampling was 50 and 948 for the SF and GP areas, respectively. In November, the number of spores was 344 and 1171 for the same areas, respectively. Thus, a greater number of spores in the GP area in both sampling periods as well as a larger number (seven) of AMF species were found in November (Table IV). In April, from the 
SF area, dominance of Glomus macrocarpum was observed as well as the presence of Glomus etunicatum and Acaulospora sp. In the GP area, there was dominance of Glomus etunicatum. In the soil samples from the second sampling period, in the $\mathrm{SF}$ area, dominance of Glomus macrocarpum was also verified and presence of Acaulospora mellea, Acaulospora scrobiculata and Archeospora leptoticha was observed. In the GP area, there was a predominance of Glomus macrocarpum as well as the presence of Glomus etunicatum, Archeospora leptoticha, Glomus geosporum, Acaulospora mellea, Acaulospora foveata and Scutellospora weresubiae.

\section{TABLE IV}

Arbuscular mycorrhizal fungi (AMF) species from secondary forest (SF) and grass pasture (GP) in soil samples taken in April and November, 2000, in Paraty, RJ.

\begin{tabular}{|l|c|c|c|c|}
\hline & \multicolumn{2}{|c|}{ April } & \multicolumn{2}{c|}{ November } \\
\hline AMF species & SF & GP & SF & GP \\
\hline Acaulospora foveata & - & - & - & + \\
\hline Acaulospora mellea & - & - & + & + \\
\hline Acaulospora scrobiculata & - & - & + & - \\
\hline Acaulospora sp. & + & - & - & - \\
\hline Archeospora leptoticha & - & - & + & + \\
\hline Glomus etunicatum & + & $+*$ & - & + \\
\hline Glomus geosporum & - & - & - & + \\
\hline Glomus macrocarpum & $+*$ & - & $+*$ & $+*$ \\
\hline Scutellospora weresubiae & - & - & - & + \\
\hline
\end{tabular}

$+=$ presence of AMF; $-=$ absence of AMF; *: dominant population in the community.

Fifty-four P-solubilizing bacteria and $18 \mathrm{P}$ solubilizing fungi isolates were obtained from both areas at Paraty in April and November. For taxonomic purposes, three P-solubilizing fungi isolates (7, 9 and 19) and four P-solubilizing bacteria isolates $(8,9,50$ and 55) were chosen. The P-solubilizing fungi isolates (7 and 9) from Paraty and the isolate (19) from Galicia were identified as Aspergillus sp. For P-solubilizing bacteria, the similarity anal- ysis of the sequences using BLAST and FASTA suggested that isolate 8 is Enterobacter aerogenes (99\% of identity), isolate 55 is Bacillus megaterium (99.5\%). Isolates 9 and 50 were closest to an uncultured soil bacterium ( $99 \%$ of identity), belonging to Enterobacteriaceae (Valinsky et al. 2002).

\section{DISCUSSION}

The superior performance of GL and GELP media for P-solubilizing bacteria isolation showing the highest number of P-solubilizing bacteria might be due to the presence of yeast extract in these media. Similar results were found by Sylvester-Bradley et al. (1982) where a higher number of P-solubilizing bacteria over fungi was obtained of soil from the Brazilian Amazon. Moreover, these growth media also allowed a better visualization of the $\mathrm{P}$ solubilization halo. On the another hand, a higher number of P-solubilizing fungi was obtained with GES and GAGES media. Probably some component of this media had favored the growing of fungi over bacteria.

The reason that $\mathrm{P}$-solubilizing fungi in soil from the SF area (second sampling) were isolated using any of the growth media was probably due to a variation in the fungi community. This behavior, however, is not related to precipitation and temperature variation, since in both sampling periods the precipitation and temperature are historically similar. It is possible that the larger plant diversity in the SF as compared to the GP area could affect the community of P-solubilizing fungi making it more diverse, promoting this variation between the sampling periods.

The results from the first sampling are in agreement with Sylvester-Bradley et al. (1982) who observed a lower number of P-solubilizing fungi than P-solubilizing bacteria in soil from the Brazilian Amazon using GL, GES, GAGES and GELP media. Nahas et al. (1994), who quantified the number of P-solubilizing microorganisms in 13 different soils with different vegetation types in São Paulo State, also observed a lower number of P- 


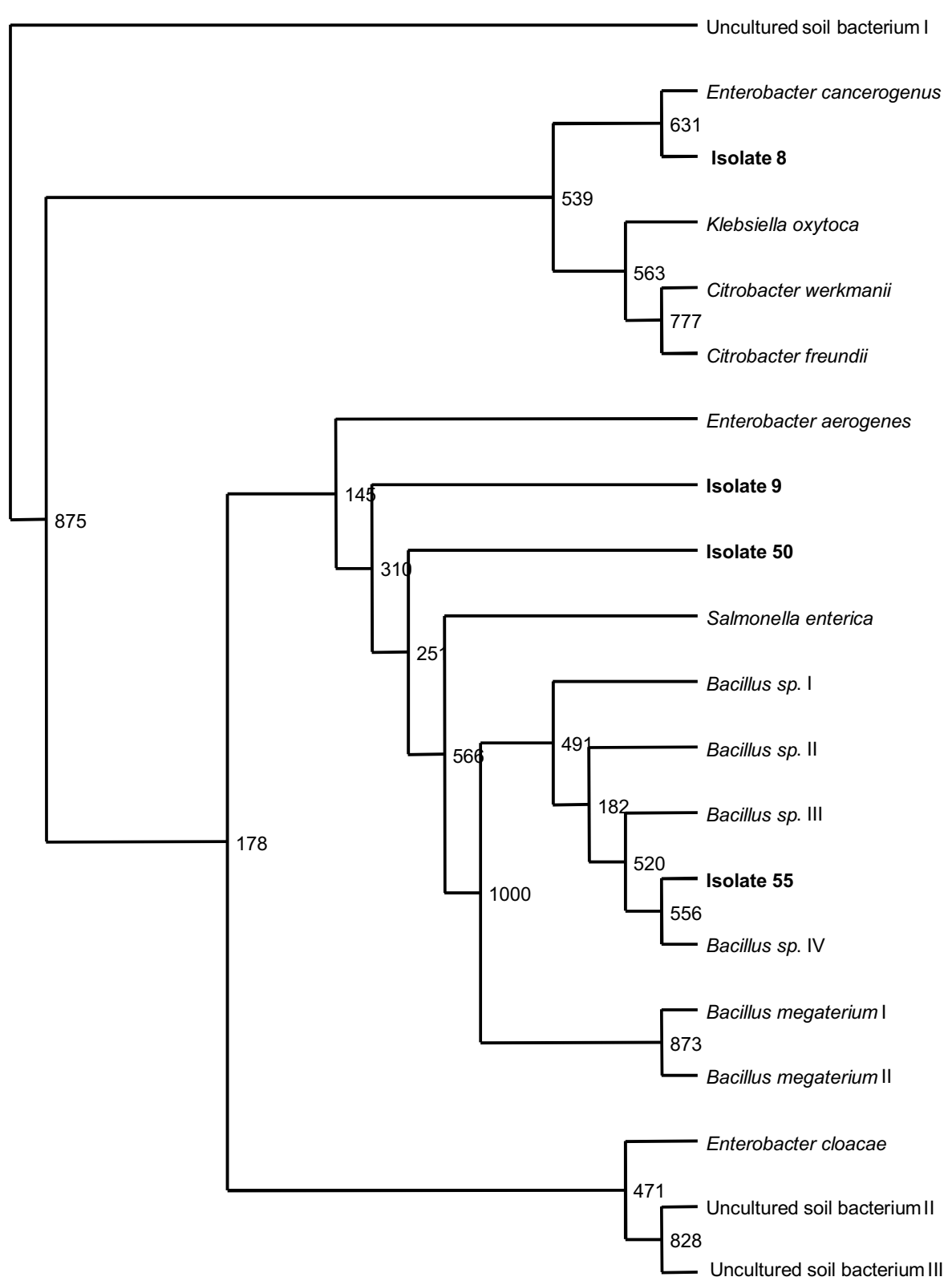

Fig. 1 - Phylogenetic analysis of the 16 SrDNA sequence from P-solubilizing bacteria isolates.

solubilizing fungi as compared to P-solubilizing bacteria. On the other hand, Souchie (unpublished data) using these growth media isolated more P-solubilizing fungi (70\%) than P-solubilizing bacteria (30\%) in soils from the Brazilian semi-arid region.

Sylvester-Bradley et al. (1982) observed a higher number of total microorganisms in the rhizo- sphere of legumes as compared to grasses. A similar observation was verified in this study, where a larger number of total microorganisms were observed in the SF area as compared to GP, using GELP medium. However, there was no statistical difference among SF and GP with the other growth media. The only exception was the larger number of total fungi in the GP area when GAGES medium was used. In the 
$\mathrm{SF}$ area there is greater plant diversity with a larger number of legume species than in the GP area, where there is a prevalence of grasses, corroborating the results obtained by Sylvester-Bradley et al. (1982). Nahas (1999) suggests that legumes species increase solubilizing microorganisms by consequence of the soil enrichment by nitrogen. It is possible that this factor had influence on the another differences observed in this work, as the larger number of $\mathrm{P}$-solubilizing bacteria and P-solubilizing fungi on SF area.

The results of AMF in this study are in agreement with Caproni et al. (2003), who also found that seasonal fluctuations affected the density of spores and number of species in revegetated degraded areas in the Brazilian Amazon. Moreover, these authors also detected a dominance of Glomus macrocarpum in the areas evaluated. Trufem (1990) also detected a greater abundance of spores of Glomus macrocarpum in a study carried out in the Atlantic forest on Cardoso Island, São Paulo, Brazil. Similarly, Carrenho et al. (2001) also verified that Glomus macrocarpum was the most observed (100\% of soil samples) in the first year of a field experiment with corn in São Paulo.

In this work, a greater number of AMF spores was observed in the grass pasture area in both sampling periods. Fischer et al. (1994) also verified lower number of AMF propagules in a secondary tropical forest area compared to a pasture area dominated by grasses. Similarly, Oehl et al. (2003) also detected a highest number of AMF spores and species in grasslands. Munyanziza et al. (1997) observed that the number of spores of AMF in undisturbed forests is low and increases with low to moderate degrees of disturbance, while species diversity, assessed on the basis of spore morphology, does not usually peak in natural ecosystems. Caproni et al. (2003) found a lower density of spores in primary forest compared to a 2 year old reforested area. These authors attributed their results to the greater stability of the primary ecosystem, less competition by niches allowing the AMF multiplication even with a low sporulation rate. In the same way, Sieverding (1991) related that variation in plant cover is a factor that directly affects the AMF multiplication. A higher number of spores is frequently attributed to plants with an abundant root system with fast growth rate and a high capacity to supply photosynthate to the fungi, as is the case of grasses (Daniels Hetrick and Bloom 1986). However, the lower AMF diversity observed in the SF area does not necessarily indicate that species were absent. For instance, Sieverding (1991) reported dominance of AMF species non-pioneers ( $\mathrm{K}$ species) that do not induce high sporulation rate. Douds and Millner (1999) related that measurement of the diversity of AMF communities in field soils presents a variety of challenges, among them the difficulty of identifying field collected spores, the detection of non-sporulation members of the community, and the lack of relation between functional diversity and the morphological diversity of spores used to delineate species.

The fact that all identified P-solubilizing fungi belong to Aspergillus genus agrees with several authors (Whitelaw et al. 1999, Seshadri et al. 2004, Wakelin et al. 2004, Wang et al. 2005) where Aspergillus or Penicillium has been described as genus of P-solubilizing fungi. In the same way, analysis of $16 \mathrm{~S}$ rDNAs from P-solubilizing bacteria isolates showed similarities to $16 \mathrm{~S}$ rDNA sequences from previously identified soil isolates in the GenBank database (Figure 1). There are studies reporting bacteria from the Bacillus genus and Enterobacteriaceae family with potential to promote $\mathrm{P}$ solubilization. Rodriguez and Fraga (1999) related that strains from Pseudomonas, Bacillus and Rhizobium are among the genera with the greatest potential for P solubilization. Silva Filho and Vidor (2001) detected solubilization of calcium phosphate by enterobacteria in growth medium amended with ammoniacal N. Hwangbo et al. (2003) showed that P solubilization by Enterobacter intermedium was mediated through the liberation of acids into the growth medium, mainly 2- ketogluconic acid. Thus, the solubilizers identified are similar to other organisms already related as phosphate solubilizing. 
Future evaluation of in vitro/vivo phosphate solubilization ability of several P sources by these P-solubilizing isolates could be an interesting study in order to improve its use as a plant mineral nutrition promoter.

\section{CONCLUSIONS}

1 - The most efficient P-solubilizing bacteria were identified as Enterobacteriaceae and Bacillus sp.

2 - The most efficient P-solubilizing fungi were identified as Aspergillus sp.

3 - There was dominance of Glomus macrocarpum in the secondary forest and grass pasture areas.

4 - The greatest number of P-solubilizing bacteria was isolated using GL and GELP growth media, which also facilitated the visualization of solubilization halo.

5 - The greatest number of P-solubilizing fungi was isolated using GAGES and GES growth media.

\section{ACKNOWLEDGMENTS}

Edson Souchie is grateful to CAPES (Coordenação de Aperfeiçoamento de Pessoal de Nível Superior) /PDEE (Programa de Doutorado com Estágio no Exterior) for the grant. Authors are also grateful to PRODETAB (Programa de Apoio ao Desenvolvimento de Tecnologia Agropecuária para o Brasil) for the financial support. Thanks to Paul Bishop and Karen Ferrel for English corrections.

\section{RESUMO}

Avaliaram-se as comunidades de bactérias, fungos solubilizadores de fosfato e fungos micorrízicos arbusculares em dois diferentes ecossistemas. Foram feitas amostragens em duas áreas de Mata Atlântica, em Paraty - RJ, Brasil, uma de floresta secundária e outra de pastagem. Foram avaliados quatro meios de cultura: GL (glicose e extrato de levedura), GES (glicose, extrato de solo,
$\mathrm{KNO}_{3}, \mathrm{CaCl}_{2}, \mathrm{MgSO}_{4}, \mathrm{NaCl}$, FeEDTA solução de micronutrientes), GAGES (glicose, extrato de solo, arabinose, glicerol, $\mathrm{CaCl}_{2}, \mathrm{MgSO}_{4}$ e $\mathrm{NaCl}$ ) e GELP (glicose, extrato de solo, extrato de levedura, peptona, $\mathrm{CaCl}_{2}$, $\mathrm{MgSO}_{4}$ e $\mathrm{NaCl}$ ) para isolamento de microrganismos solubilizadores de fosfato. A identificação das bactérias solubilizadoras foi baseada na análise do $16 \mathrm{~S} \mathrm{rDNA}$, enquanto que os fungos solubilizadores e os micorrízicos arbusculares foram identificados pela sua morfologia. O maior número de bactérias solubilizadoras foi obtido usando os meios GL e GELP. O maior número de fungos solubilizadores foi obtido com os meios GAGES e GES. As bactérias solubilizadoras foram identificadas como Enterobacteriaceae e Bacillus sp., e os fungos como Aspergillus sp. Glomus macrocarpum e Glomus etunicatum foram as espécies de fungos micorrízicos dominantes nas áreas de floresta secundária e pastagem, respectivamente.

Palavras-chave: fosfato, Enterobacteriaceae, Mata Atlântica, Glomeromycota, microrganismos do solo.

\section{REFERENCES}

AzCón R And El-Atrash F. 1997. Influence of arbuscular mycorrhizae and phosphorus fertilization on growth, nodulation and $\mathrm{N}_{2}$ fixation $(15 \mathrm{~N})$ in Medicago sativa at four salinity levels. Biol Fertil Soils 24: 81-86.

BARNETT HL AND HunTER BB. 1972. Illustrated genera of imperfect fungi, Minneapolis: Burgess Publishing Company, $241 \mathrm{p}$.

CAProni AL, Franco AA, Berbara RLL, TrufEM SB, Granha JRDO And Monteiro AB. 2003. Ocorrência de fungos micorrízicos arbusculares em áreas revegetadas após mineração de bauxita em Porto Trombetas, Pará. Pesq Agropec Bras 38: 1409-1418.

Carrenho R, Silva ES, Trufem SFB and Bononi VLR. 2001. Successive cultivation of maize and agricultural practices on root colonization, number of spores and species of arbuscular mycorrhizal fungi. Bras J Microbiol 32: 262-270.

Chen X, Tang JJ, Zhi GY and Hu SJ. 2005. Arbuscular mycorrhizal colonization and phosphorus acquisition of plants: effects of coexisting planta species. Appl Soil Ecol 28: 259-269. 
Clark RB And Zeto SK. 2000. Mineral acquisition by arbuscular mycorrhizal plants. J Pl Nutr 23: 867-902.

DANiels Hetrick BAD AND BloOm J. 1986. The influence of host plant on production and colonization ability of vesicular-arbuscular mycorrhizal spores. Mycologia 78: 32-36.

Douds DD AND Millner P. 1999. Biodiversity of arbuscular mycorrhizal fungi in agroecosystems. Agric Ecos Environ 74: 77-93.

EMBRAPA. 1997. Centro Nacional de Pesquisa de Solos (Rio de Janeiro, RJ). Manual de métodos de análise de solo. $2^{\mathrm{a}}$ ed., SPI (Embrapa Solos. Documentos, 1), Brasília, $212 \mathrm{p}$.

FERREIRA DF. 1999. Programa Sisvar Versão 4.6 (Build 61). Disponível em: http://www.dex.ufla.br/danielff/ dff02.htm.

Fester T, Maier W And Strack D. 1999. Accumulation of secondary compounds in barley and wheat roots in response to inoculation with an arbuscular mycorrhizal fungus and co-inoculation with rhizosphere bacteria. Mycorrhiza 8: 241-246.

Fischer CR, JANOS DP, PERRY DA, LiNDERMAN RG AND Sollins P. 1994. Mycorrhiza inoculum potentials in tropical secondary succession. Biotropica 26: 369-377.

Flores-Aylas WW, SAggin-Júnior OJ, Siqueira JO AND DAVIDE AC. 2003. Efeito de Glomus etunicatum e fósforo no crescimento inicial de espécies arbóreas em semeadura direta. Pesq Agropec Bras 38: $257-266$.

GANGE AC, BRown VK AND FARMER LM. 1990. A test of mycorrhizal benefit in an early successional plant community. N Phytol 115: 85-91.

Gerdemann JW And Nicolson TH. 1963. Spores of mycorrhizal Endogone species, extracted from soil by wet-sieving and decanting. Trans Brit Mycol Society 46: 235-244.

Giovannetti L, Ventura S, Bazzicalupo M, FANI R AND MATERASSI R. 1990. DNA restriction fingerprint analysis of the soil bacterium Azospirillum. J Gen Microbiol 136: 1161-1166.

GyANEShWAR P, KumAR GN, PAREKH LJ AND POOLE PS. 2002. Role of soil microorganisms in improving P nutrition of plants. Pl Soil 245: 83-93.
Hwangbo H, Park RD, Kim YW, Rim YS, PARK KH, KIM TH, SUH JS AND KIM KY. 2003. 2 Ketogluconic acid production and phosphate solubilization by Enterobacter intermedium. Curr Microbiol 47: 87-92.

JANOS DP. 1980. Mycorrhizae influence tropical succession. Biotropica 12 (Suppl.): 56-64.

JENKINS WR. 1964. A rapid centrifugal-flotation technique for separating nematodes from soil. Pl Dis Rep 48: 692 .

JOHANSSON JF, PAUL LR AND FINLAY RD. 2004. Microbial interactions in the mycorrhizosphere and their significance for sustainable agriculture. FEMS Microbiol Ecol 48: 1-13.

LANE DJ. 1991. 16S/23S rRNA sequencing. In: STACKEBRANDT E AND GoOdFELlow M (Eds), Nucleic Acid Techniques in Bacterial Systematics. New York: J Wiley \& Sons, p. 115-147.

Munyanziza E, Kehri H And Bagyaraj DJ. 1997. Agricultural intensification, soil biodiversity and agro-ecosystem function in the tropics: the role of mycorrhiza in crops and trees. Appl Soil Ecol 6: $77-85$.

NAHAS E. 1999. Solubilização microbiana de fosfatos e de outros elementos. In: SiqueIRA JO, MOREIRA FMS, LOPES AS, GuILHERME LRG, FAQUiN V, Furtini Neto AE AND CARvalho JG (Eds), Inter-relação fertilidade, biologia do solo e nutrição de plantas. Viçosa: SBCS, Lavras: UFLA/DCS, p. 467-486.

Nahas EM, Centurion JF And Assis LC. 1994. Microganismos solubilizadores de fosfato e produtores de fosfatases de vários solos. Rev Bras Ci Solo 18: 43-48.

Oehl F, Sieverding E, Ineichen K, Mader P, BOLLER T AND WIEMKEN A. 2003. Impact of land use intensity on the species diversity of arbuscular mycorrhizal fungi in agroecosystems of Central Europe. Appl Environ Microbiol 69: 2816-2824.

Rodriguez H AND Fraga R. 1999. Phosphate solubilizing bacteria and their role in plant growth promotion. Biotech Adv 17: 319-339.

Ruiz-Lozano JM, Collados C, Barea JM And AZCón R. 2001. Arbuscular mycorrhizal symbiosis can alleviate drought-induced nodule senescence in soybean plants. N Phytol 151: 493-502. 
Seshadri S, Ignacimuthu S AND LaKshminaRASIMHAN C. 2004. Effect of nitrogen and carbon sources on the inorganic phosphate solubilization by different Aspergillus niger strains. Chem Eng Commun 191: 1043-1052.

SIEVERDING E. 1991. Vesicular-arbuscular mycorrhiza management in tropical agrosystems. Eschborn, GTZ, 317 p.

Silva FILho GN AND VIDOR C. 2000. Solubilização de fosfatos por microrganismos na presença de fontes de carbono. Rev Bras Cienc Solo 24: 311-319.

Silva Filho GN AND Vidor C. 2001. Atividade de microrganismos solubilizadores de fosfatos na presença de nitrogênio, ferro, cálcio e potássio. Pesq Agropec Bras 36: 1495-1508.

SylVESTER-BRADLEY R, ASKaWA N, LATORRACA S, Magalhães FMM, Oliveira LA And PeREIRA RM. 1982. Levantamento quantitativo de microrganismos solubilizadores de fosfato na rizosfera de gramíneas e leguminosas forrageiras na Amazônia. Act Amaz 12: 12-22.

Toro M, AzCón R AND BAREA JM. 1997. Improvement of arbuscular mycorrhiza development by inoculation of soil with phosphate-solubilizing rhizobacteria to improve rock phosphate bioavailability $\left(\mathrm{P}_{32}\right)$ and nutrient cycling. Appl Environ Microbiol 63: 4408-4412.
Trufem SFB. 1990. Aspectos ecológicos de fungos micorrízicos vesículo-arbusculares da mata tropical úmida da Ilha do Cardoso, SP, Brasil. Act Bot Bras 4: $31-45$.

VALINSKY L ET AL. 2002. Analysis of bacterial community composition by oligonucleotide fingerprinting of rRNA genes. Appl Environ Microbiol 68: 3243-3250.

VAN DER HEIJDEN MGA, WIEMKEN A AND SANDERS IR. 2003. Different arbuscular mycorrhizal fungi alter coexistence and resource distribution between co-occurring plant. N Phytol 157: 569-578.

WAKELIN SA, WARREN RA, HARVEY PR AND RYDER MH. 2004. Phosphate solubilization by Penicillium spp. closely associated with wheat roots. Biol Fert Soils 40: 36-43.

WANG GH, ZhOU DR, YANG Q, Jin J AND LiU XB. 2005. Solubilization of rock phospate in liquid culture by fungal isolates from rhizosphere soil. Pedosphee 15: 532-538.

Whitelaw MA, HaRden TJ AND Helyar KR. 1999. Phosphate solubilisation in solution culture by the soil fungus Penicillium radicum. Soil Biol Biochem 31: 655-665. 